BUFA-DÖRR Zsuzsanna, SEBESTYÉN Ágnes, IZSÁK Bálint, TÖRÖ Károly, VARGHA Márta

Nemzeti Népegészségügyi Központ, Közegészségügyi Laboratóriumi Föosztály, Budapest

E-mail: izsak.balint@nnk.gov.hu

DOI: https://doi.org/10.29179/EgTud.2021.3.41

\title{
A csapvíz ólomtartalmának országos felmérése
}

\section{Összefoglalás:}

A XX. század első feléig bevett gyakorlat volt ólomcsövek használata az ivóvízhálózatok kiépítése során. Később ez fokozatosan visszaszorult, napjainkban pedig már nem használható ólomcső e célra. Ugyanakkor sok helyen, föleg régi épületekben még ma is megmaradtak, nem kerültek kicserélésre. Az ólom káros egészséghatása jól ismert, a csövekből pedig jelentős mennyiségú ólom oldódhat az ivóvízbe, így ez egy figyelmet igénylö közegészségügyi kérdés. A probléma mértékének becsléséhez azonban szükséges volt egy reprezentatív, országos felmérés, erre került sor 2017-2020 között az EFOP-1.8.0-VEKOP-17-2017-00001 projekt keretein belül, az ún. „Feltáró monitoring" program során. Az ország településeinek kockázati kategóriába sorolása után kiválasztásra került 58 terület, ahol több mint 2700 mintavételi helyről 5000-nél is több minta levételére és vizsgálatára került sor. Az eredmények alapján sor került az előzetes kockázati besorolások pontosítására, a kockázatos területek meghatározására és az érintett lakosszám becslésére. A probléma Budapest esetében jelentős, itt 620.000 ember lehet kitett az ivóvízben lévő ólom jelentette kockázatnak, az épületek 25 \%-a magas vagy nagyon magas kockázati kategóriába tartozik. Jobb a helyzet a többi 5000 fö feletti városban, összesen 120.000 fö lehet érintett, az épületek mindössze 3 \%-a magas vagy nagyon magas kockázatú. Az 5000 fő alatti települések esetében kedvező a helyzet: az épületek alacsony vagy nagyon alacsony kockázati besorolást kaptak. Vizsgáltra került továbbá, hogy milyen tényezők befolyásolhatják az ivóvízben megjelenő ólomtartalmat (épület-kor, vízhálózat-felújítás, stb.), mivel lehet csökkenteni a kockázatokat, illetve a résztvevők egyedi értékelést kaptak az eredményeikről. A kutatás alapján tájékoztató anyagok, on-line elérhető, cím szerint kereshető kockázati térképek és egyéni kockázatbecslést segítő, ún. „Ólomkockázati kalkulátor” is készült. Továbbá a lakosság részére ingyenes ólomvizsgálati lehetőség is rendelkezésre állt a „Nyitott laboratórium" program során. Összesen 369 településröl, több mint 3700 helyszínről érkeztek be a lakosok által levett vízminták, melyek eredményei alapján egyedi értékelést kaptak a résztvevők. A „Nyitott laboratórium” program nem reprezentatív ugyan, de az eredményei egybevágnak az országos felmérés eredményeivel.

Kulcsszavak: ivóvíz, ólom, vízhálózat-felújítás 